$\begin{array}{llr}\text { KULTURA } & \text { POLSKA A KADEMIA NAUK } & \text { ISSN 0023-5172 } \\ \text { i } & \text { KOMITET SOCJOLOGI } & \text { 2300-195x } \\ \text { SPOLECLENSTWO } & \begin{array}{l}\text { INSTYT T STUDIÓW POLITYCZNYCH } \\ \text { 2019, nr 4 POLES IN THE WORLD OF LATE CAPITALISM }\end{array}\end{array}$

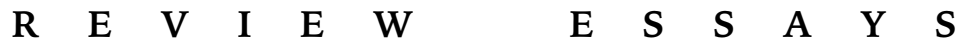

ANTONI Z. KAMIŃSKI

Institute of Political Studies PAS

BARTŁOMIEJ K. KAMIŃSKI

Central European, Russian and Eurasian Studies,

University of Maryland, College Park

\section{ARE DEFENDERS OF LIBERAL DEMOCRACY ITS GRAVEDIGGERS?*}

Pippa Norris and Ronald Inglehart. 2019. Cultural Backlash: Trump, Brexit, and Authoritarian Populism. New York, N.Y.: Cambridge University Press.

Steven Levitsky and Daniel Ziblatt. 2018. How Democracies Die. New York: Crown Publishing Group.

Yascha Mounk. 2018. The People vs. Democracy: Why Our Freedom is in Danger and How to Save It. Cambridge, Mass.-London: Harvard University Press ${ }^{1}$.

Liberal democracies have displayed an impressive ability to overcome tensions generated by political economic and cultural and technological change and adapt to new circumstances. Yet, the string of these successful adaptations may have come to an end. The growing popularity of populist anti-establishment movements and political parties has provoked increased interest in their causes, raising the possibility of democracy's extinction. A series of events since 2016, spearheaded by Brexit and Don-

Correspondence addresses: kaminski@isppan.waw.pl; ORCID: 0000-0001-8772-3794 [A.Z.K.]; bkaminsk@umd.edu; ORCID: 0000-0001-6242-7702 [B.K.K]

* We would like to thank Rafał Wierzchosławski, Emilia Kowalewska, Andrew Nagorski, Marek Okólski, Arthur Rachwald, Helena Chmielewska-Szlajfer, Potr Chmielewski, and Frank Ward for very useful comments on earlier versions of this essay. Usual caveats apply with authors assuming full responsibility for any errors or omissions.

${ }^{1}$ Numbers of quoted pages in the text. 
ald Trump's presidency, signals a possible realignment of political forces not only in the US and UK but also in a number of other democracies. On these grounds, the authors of the three reviewed books express deep concerns about the future of liberal democracy not only in the US but also elsewhere. We shall focus on the US as this is the main theme of their analyses. While they also allude to illiberal trends elsewhere, these-with a possible exception of Cultural Backlash-are not subject to a rigorous in-depth comparative examination.

The fact that the authors are from prestigious American universities, trend-setters in scholarly research including political science, is not their only common trait. They all see recent electoral successes of anti-establishment political parties and movements/forces within democratic states, in particular the victory of Donald Trump in the American presidential elections in 2016, as a shift towards authoritarian populism, which is a mortal threat to liberal democracy. "Donald Trump's election to the White House-notes Munch (p. 2) - has been the most striking manifestation of democracy's crisis." The authors of Cultural Backlash explain (p. 3): "We view Trump as a leader who uses populist rhetoric to legitimize his style of governance, while promoting authoritarian values that threaten the liberal norms underpinning American democracy." In order to avoid any misunderstanding, they hasten to add in the next paragraph that Trump is not unique as authoritarianism " [...] has a long history that peaked during the era of Bolshevism and Fascism, and has seen resurgence since the late-twentieth century."

For the authors of the reviewed books, Donald Trump represents a disruption of the liberal trend-halted temporarily by President Reaganfrom the Civil War to the New Deal, to the civil rights movement and to the election of Barack Obama. Trump, and the Republicans in general, are the main villains in the unfolding assault on liberal democracy.

\section{AUTHORITARIAN POPULISM: TEMPORARY DISRUPTION OF POST-MODERN SOCIALIST TRAJECTORY?}

For Pippa Norris and Ronald Inglehart, this is-as the title of their book Cultural Backlash: Trump, Brexit, and Authoritarian Populism announces - a temporary disruption, albeit their analysis goes further than the title suggests. Donald Tramp's presidential victory, and Brexit are the main, but not the only examples that serve to illustrate the present predicament of Western civilization. As a matter of fact, the book is mostly devoted to an elaborate statistical analysis providing support to their contentions. The 
cultural backlash is, according to them, only a temporary deviation from the secular path in cultural development.

The main message of the book is that the West is witnessing a "cultural silent revolution" 2 which provoked an "authoritarian backlash among social conservatives." "We hypothesize that socially liberal values are spreading through intergenerational population replacement and demographic shifts, causing traditionalists (concentrated among the less educated and older birth cohorts) to feel threatened, perceiving the respect for their core values and social mores as rapidly eroding" (p. 87).

The former cultural majority has become a minority. Traditional values and norms regarding sex life, patriotism, religious practices, the role of women, and the status attributed to racial and ethnic minorities, have been gradually vanishing, replaced by the post-materialist or post-modern culture. New public priorities have emerged, including environmental protection, gender and racial equality, and rights for the LGBTQ community. "A substantial body of evidence confirms that existential security is conducive to open-mindedness, social tolerance, and trust, secularization and acceptance of diverse lifestyles, identities, and values" (p. 89). To demonstrate the evolution of value systems across generations, Norris and Inglehart distinguished four age cohorts: The Interwar cohort-born before 1945; Baby Boomers-born between 1946 and 1964; Generation X -1965-1979; and Millennials-1980-1996. Both in Europe and the USA the older age cohorts are gradually disappearing, with the Millennials having become the largest segment of adult population. In consequence, "The tipping point of the hypothesis holds that traditional socially conservative values have gradually fallen out of step with the changing cultures of the Western societies. This might conceivably generate a spiral of silence effect, where social conservatives retreat from the public sphere, suppressing the overt expression of politically incorrect views [sic!-A\&BK]" (p. 90). ${ }^{3}$

${ }^{2}$ In the meaning popularized originally by Ronald Inglehart in his book The Silent Revolution: Changing Values and Political Styles Among Wester Publics (1977).

${ }^{3}$ The "conservative" voting patterns of older cohorts in 2016 seem to contradict Inglehart's earlier finding suggesting post-material values do not change with age. This was a conclusion drawn from post- "Silent Revolution survey" carried out around ten years later and published in Culture Shift in Advanced Industrial Society (Inglehart 1990). Most recent 2019 Gallup survey suggests that the trend (see https://news.gallup.com/poll/275792/remainedcenter-right-ideologically-2019.aspx?mod=article_inline) of a generational leftward drift might have come to an end: the share of liberals increased from $17 \%$ in 1992 to $26 \%$ in 2018 and then declined to $24 \%$ in 2019 . The share of conservatives ticked up from $35 \%$ to $37 \%$. It remains to be seen whether this is a statistical blip. 
Thus, although the growing personal security has led to changes in culture that "prioritize individual free-choice and self-expression" (p. 32), this is not yet mirrored in electoral outcomes. As the Millennials are less inclined to participate in elections than the older age cohorts, this change has not produced as yet a more significant liberal modification of state policies. In a marked contrast, the threat has mobilized the frustrated old cohorts "who perceive that some of their most cherished core values are being eroded" to concoct the "authoritarian backlash" that brought to power right-wing populists like Donald Trump, Victor Orban, or Jarosław Kaczyński. It also boosted the electoral support for authoritarian-populist parties in Austria, Scandinavia, France, Italy, and Latin America.

The notion of populism, according to the authors is "notoriously difficult to pin down precisely" (p. 65). They contrast it to the liberal idea that supports pluralism, political representation and liberal-democratic institutions providing checks and balances on executive power. While populism claims the sovereignty of the people over the established power structures, "[t]he main cleavages concern populist-pluralist divisions in orientations toward the legitimate source of governance, left-right divisions over economic values, and authoritarian-libertarian over cultural values" (p. 65). Thus, the authors see populism as a threat to minority rights, free press, judicial independence, freedom of expression, and institutions underpinning civil society.

"We define populism minimally as a rhetorical style of communications claiming that (i) the only legitimate democratic authority flows directly from the people, and (ii) established power-holders are deeply corrupt, and self-interested, betraying the public trust. We argue that populist narratives can be reduced to these-and only these-twin components" (p. 66).

Norris and Inglehart do not consider the possibility that the "established power-holders" may in fact be deeply corrupt, and that a social revolt against such a rotten regime can only find legitimacy in the idea of the priority of society over the regime. This was the very idea behind the Solidarity movement in Poland in 1980s. This does not deny the pertinence of the notion of populism, but rather indicates a certain defect of the definition. On the other hand, we may agree that what distinguishes populism is the claim that "legitimate democratic authority" is "derived from unconstrained majority rule" (p. 66).

The authors distinguish between the authoritarian and the libertarian variants of populism that differ in their cultural values rather than in their rhetorical style. In defining the term "authoritarian", they refer to 
values embedded within a group culture. They define authoritarianism "[...] as a cluster of values prioritizing collective security for the group at the expense of liberal autonomy for the individual" (p. 7). The term "authoritarian values" comprises a cluster of three components: (i) conformity - strict adherence to group's conventions and traditional customs; (ii) security - safety and protection of the group against risks, and the perception of outsiders as a threat to the group or its mores; and (iii) loyalty - support of the group and its leaders (p. 71). They use a continuous scale ranging from the most authoritarian pole to the most libertarian one. Norris and Inglehart enclose a whole list of items characterizing the authoritarian value system, they are: conservative, ethnocentric, disapproving of gender equality, of fluid gender roles, gay marriages, etc. "In practice, authoritarian and populist values are often closely associated with socially conservative attitudes and behavioral norms" (p. 72).

Libertarian populism is just the opposite: it emphasizes " $[\ldots]$ the importance of personal freedoms, celebrates pluralist diversity, and values individuality more than collective security" (p. 73). These values are rooted, they claim, in the thought of John Locke, James Madison or John Stuart Mill. Thus, authoritarian populism and libertarian populism are like bad and good cholesterol: one is harmful to society, while the other embodies everything that is positive.

Authoritarian populism is related to deprivation, especially amongst the working class, that is, people employed in the manufacturing industry, reporting income insecurity, living in poverty, uneducated inhabitants of rural areas, experiencing a high level of personal insecurity. The recent wave of immigration has provided a particularly strong impulse to the rising influence of authoritarian populism. As a matter of fact, "hostility toward immigration is a significant predictor of authoritarian values" (p. 176). And such attitudes are more related to cultural factors than to economic ones. No wonder, if "hostility toward multiculturalism, racial equality and minority rights, ethnic diversity, and immigration is [...] regarded as the defining feature of the Authoritarian-Populist parties [...]" (p. 182).

As electoral behavior of citizens depends on their values, there should be a high level of congruence between the dominant value systems and the support for parties whose programs incorporate them. Moreover, as ideological profiles of voters are linked to their generational cohorts, educational level, and habitat, the authors posit that the younger voters prefer liberal or libertarian (populist) parties, while the older ones tend to support conservative and populist parties. This thesis is only to some extent 
confirmed by the data for, at the same time, they found that both in Europe and USA younger cohorts are far less likely to vote (p. 287). There are other factors that influence voting behavior, particularly the electoral systems-Majoritarian or Proportional representation. On the basis of evidence, they conclude that Proportional representation systems, "[...] with low thresholds facilitate party fragmentation and extremism, which, in turn, is associated with hung parliaments, unstable and ineffective governments, and, in extreme cases, even state failure" (p. 315).

In their final comments, Norris and Inglehart concede that populism may be "[...] a force of good in the world when grass roots reform movements help reduce corruption, strengthen responsive governance, expand the issue agenda that are debated and the electoral choices on the ballot, and reengage participation among groups alienated by mainstream party politics" (p. 461). ${ }^{4}$ But this applies to the libertarian version of populism, for authoritarian populism presents nothing but dangers to democracy.

While we have no problem with accepting the data and derived from them theses about the cultural change backlash, their diagnosis of threats to the liberal democratic system is controversial at best. The essence of democracy is moderation. As they themselves note, since 1994 "the moderate middle has disintegrated". ${ }^{5}$ Both variants of populism, authoritarian and libertarian, in their radical versions, present a threat to democracy. They both destroy the institution of citizen as a rational human being acting in the pursuit of not only personal fulfillment but also for the common wealth of the community, sometimes to the extent of making personal sacrifices for its stake.

Actually, one is struck by the lack of any serious reference to the notion of citizen in the whole book. We have not found it in the Index. It appears a few times in the context of voting behavior. It appears in the following sentence: "Almost two decades ago, the rise of 'critical citizen' was documented, showing that many people endorsed democratic ideals but they were deeply disenchanted with the performance of representative institutions." This provided "[...] opportunities for populists to turn rightful skepticism about liberal democracy into a deeper cynicism about 'the establishment'" (p. 449). Does this mean that the "critical citizens" have been lured into providing support to the authoritarian populists? Or

\footnotetext{
4 They refer to Margaret Canovan Trust the people! Populism and the two faces of democracy (1999).

${ }^{5}$ They also note that "well before the election of Trump [...] members of Congress had become sorted into cohesive and deeply opposing camps without the capacity to compromise on many issues" (p. 448).
} 
does it perhaps indicate that the post-materialist value system is void of values that could provide the basis for the survival of the institution of citizenship?

Looking at the continua we would assume that the value system of citizenship could place itself somewhere in their middle. Yet, the authors, while analyzing the continua, use in their assessments a dichotomic classification: one pole is bad; the opposite one is good. As Benjamin Constant remarked, "the extremes not only touch, but also follow each other." ${ }^{6}$ The polarization of views and values, whatever its direction, is dysfunctional for democracy. Thus, the authors blame authoritarian populism for failing to "recognize the virtues of deliberation and consensus-building," but fail to note that the term "political correctness" has been invented and has come to dominate the intellectual life of the West in line with its libertarian orientation. Thus, the bureaucratic censorship of the communist countries has been replaced by an even more harmful sectarian pressure. Does this lead to lively deliberations?

Sometimes the reasoning of Norris and Inglehart confuses: opposition to immigration is a measure of tolerance (p. 429). At the same time, they concede that the capacity to absorb immigration has limits, not only cultural, but also economic (p. 465). Thus, depending on circumstances, a rational citizen, with an openminded attitude to the world, can either welcome or oppose new immigrants. Their economic argument in favor of immigration is wanting. The evidence that the disproportionate share of entrepreneurs comes from among immigrants, as "[...] in 2016, 40 percent of Fortune's list of the 500 top US firms were owned by immigrants or their children" (p. 176-7), probably refers to certain categories of immigrants (such as Jews, Chinese, Hindus), but not to the great majority of recent African immigrants to Europe or Latin American immigrants to the United States.

Another important indicator, the attitude toward minorities, can also have a situational character. A minority with a high mobilization potential can force its interests against the interest of the majority. In case such a minority can win/lose a large pay off at a minor cost/gain to individual members of the majority, the minority will prevail. Thus, we can have a tyranny of majority as well as a tyranny of a strategically located, disposing of a high mobilization potential, minority.

Finally, Norris and Inglehart observe that the post-materialist values of the Millennials are not effectively articulated into the political system

${ }^{6}$ «Non seulement les extrêmes se touchent, mais ils se suivent» (Constant 1997: 30). 
because of their lower propensity to participate in elections. No attempt is made to explain this phenomenon. It may be, as noticed earlier, that the post-materialist values conflict with the traditional civic ethos. This insight finds some confirmation in the following remark: "The indicators of marriage and the family are also related to voting for parties that are more authoritarian-although it cannot be determined whether this means that people become more favorable toward these values as they age or whether those with greater emphasis on social conformity and respect for traditions are more likely to marry and have children" (p. 279).

Assuming this finding is correct, it implies that individuals with an authoritarian disposition are more willing to take responsibility for the family, and in view of this, more willing to participate in public life. Hence, it also suggests that libertarianism may be destructive of values indispensable for the civic ethos to persist.

By the same token, the end of democracy may come not only from authoritarian populism but also from libertarianism; this point is conveniently overlooked in the authors' analysis.

\section{POTENTIAL FOR DEMOCRATIC BACKSLIDING: TRUMP'S PRESIDENCY}

While with younger generations inevitably crowding out older conservatives, the ballot may turn in their favor and authoritarianism may lose its prominence, the danger is that the populist assault on institutions and constitutions will succeed and authoritarian regimes will replace democracy. American system of checks and balances has historically been effective not only because of high quality of institutional design but also because its rules have been reinforced by unwritten democratic norms. Levitsky and Ziblatt focus on the question of whether Donald Trump's presidency is a threat to democracy. Their answer, incorporating also their earlier research on the breakdown of democracy in Latin America and Europe, is unambiguously affirmative. Democracy does not have to end with a bang; it usually ends with a whimper through a gradual weakening of its institutional underpinnings.

Steven Levitsky and Daniel Ziblatt developed their analysis around three major propositions describing conditions for the survival of democracies:

A. "Democracies work best-and survive longer-where constitutions are reinforced by unwritten democratic norms. Two basic norms have preserved America's checks and balances in ways we have come to take for granted: mutual toleration, or the understanding that com- 
peting parties accept one another as legitimate rivals, and forbearance, or the idea that politicians should exercise restraint in deploying their institutional prerogatives" (p. 8). The norms of mutual tolerance and institutional forbearance constituted the underpinnings of American political culture, "the soft guardrails of American democracy."

B. The Founding Fathers were wary of direct democracy, therefore, through the representative system, they aimed at diminishing direct influence of the populace. The political parties served as a protection against bringing would-be authoritarians to political offices. They functioned as gatekeepers selecting the candidates for offices. "For most American history, political parties prioritized gate-keeping over openness" (p. 41).

C. Drawing on the work of late Spanish-American political scientist Juan Linz, Levitsky and Ziblatt propose "four behavioral warning signs" that permit the identification of a politician as an authoritarian. "We should worry when a politician 1) rejects, in words or action, the democratic rules of the game, 2) denies the legitimacy of opponents, 3) tolerates or encourages violence, or 4) indicates a willingness to curtail the civil liberties of opponents, including the media" (p. 21).

Turning to the proposition A, they point to two reasons responsible for growing weaknesses of American democracy: first, the collapse of the norms of mutual tolerance and of institutional forbearance; and second, the erosion of political parties' ability to serve as effective gate-keepers against authoritarians in politics. The change in the American political culture came in the years 1964-1965, when the political community was finally opened to the blacks. Then the Civil Rights Act and the Voting Rights Act were approved by the Congress. Up to then, the political parties, the Democratic Party in particular, had been heterogeneous. The political values of Southern Democrats were often closer to Republicans than to their fellow Democrats from the North-East. "Congressional Republicans and Democrats divided on such issues as taxes and spending, government regulation, and unions, but the parties overlapped on the potentially explosive issue of race" (p. 168). Since the 1960s the composition of both of the main political parties changed leading to growing political polarization that destroyed mutual toleration and institutional forbearance.

The gatekeeping function of the political parties (proposition B) was annihilated by the recommendations of the McGovern-Fraser Commission - created in response to the tumultuous 1968 Democratic National Convention-that led to the adoption of the binding presidential primaries. 
Since " $[\ldots]$ 1972, the vast majority of the delegates to both the Democratic and Republican conventions would be elected in state-level primaries and caucuses. Delegates would be preselected by the candidates themselves to ensure their loyalty. This meant that for the first time, the people who chose the parties' presidential candidates would be neither beholden to party leaders nor free to make backroom deals at the convention; rather, they would faithfully reflect the will of their state's primary voters" (p. 49).

The popular elections of delegates open the way for authoritarian demagogues to manipulate the emotions of voters to win elections. Once they obtain the position of authority, the politicians of such a disposition can use the instruments of power to capture the "referees" and rewrite the rules of the game to "gain a decisive-and permanent-advantage over their opponents" (p. 92). The authors do not allow for the possibility that openness allows to take into account a wider range of ideas and political views in public policy making.

Is the backroom candidate selection the most effective way to select the candidate that would do a good job as a president? Such a person may be a "safe" candidate from the point of view of "party bosses", but would s/he be willing to serve the public interest? One can speculate that, had the decision been left in the hands of the Democratic Party establishment, Hilary Clinton would have been selected as its candidate in the presidential elections of 2008 instead of Barack Obama. Donald Trump—displaying neatly authoritarian "four behavioral warning signs" (see Proposition C above) would not have been an acceptable choice for the Republican establishment, but perhaps the establishments have become so alienated from society writ large that they have lost touch with the electorate's needs and values.

Although the case of the United States, and in particular the victory of Donald Trump in presidential elections, occupies the main parts of the book, the authors use examples of other nations, politicians, and political parties that fit the authoritarian label. They conclude, among others, that

"Comparing our current predicament to democratic crises in other parts of the world and at other moments of history, it becomes clear that America is not so different from other nations. Our constitutional system, while older and more robust than any in history, is vulnerable to the same pathologies that have killed democracy elsewhere" (p. 230).

There is, however, one difficulty with this reasoning: in those other cases we do not have primaries, nor did we have events similar to the inclusion of black Americans in the political process. This may suggest that the real roots of the vulnerability of modern democracies are deeper and more universal. Therefore, the relationship between the present crisis 
of American democracy and events indicated by Levitsky and Ziblatt as its causes may be spurious. So is the potential for backsliding.

Are the Republicans, and the right-wing political parties, as guilty as charged by the authors of the book? In discussing the dramatic fate of Salvador Allende's presidency in Chile, they mention that Allende's opponents were financially supported by the CIA. Yet, they fail to mention that, according to Mitrokhin's Archive, president Allende collaborated with the KGB under the cryptonym "Leader." The Soviet intelligence agency sponsored his electoral campaigns. Thus, the coup was part of Cold War history, and not an incident apart.

Another example of ideological bias concerns the case of Judge Merrick Garland. Levitsky and Ziblatt give the following account of the story:

"On March 16, 2016, President Barack Obama nominated appellate judge Merrick Garland to fill Scalia's seat. No one doubted that Garland was a qualified candidate, and by all accounts he was an ideological moderate. But for the first time in American history, the U.S. Senate refused to even consider an elected president's nominee for the Supreme Court. As we have seen, the Senate had always used forbearance in exercising its advice and consent in the selection of Supreme Court justices: Since 1866, every time a president had moved to fill a Supreme Court vacancy prior to the election of his successor, he had been allowed to do so" (p. 145).

The authors forget that political weaponization of appointments of Supreme Court Justices was earlier engineered by Democrats. It happened first in 1987 with Robert Bork and four years later with Clarence Thomas, who described the actions of the (Democrat controlled) Senate Committee as a "high-tech lynching." 7 According to the late Aaron Wildavsky (1990: 98-99), Justice Robert Bork was subject to similar treatment:

"In recent decades it had been customary for the Senate to approve the president's choices for the Supreme Court as long as they were qualified individuals and of good character. It had also been customary not to inquire closely into nominee's views on constitutional interpretation [...]. Bork was attacked not on grounds of knowledge-where his opponents could hardly have bested him-nor on grounds of personal integrity, but on grounds of policy."

Justice Bork was President Reagan's nominee, and his candidacy was subverted by the Senate Democrats on purely political grounds. Thus, the

7 In his statement before the Senate Judiciary Committee (11 October 1991), he famously said "And from my standpoint as a black American, as far as I'm concerned, it is a high-tech lynching for uppity blacks ..." (see: https://www.americanrhetoric.com/speeches/clarence thomashightechlynching.htm). 
question, we suggest, is not who the villain is, as Levitsky and Ziblatt argue, but rather what has happened with modern politics and with society. This takes us to Mounk's book.

\section{LIBERALISM IN CONFLICT WITH DEMOCRACY}

Yascha Mounk's discussion is rooted in the conviction that modern democracy and liberalism no longer constitute a cohesive whole. In fact, the critical issue in modern politics is the disjunction of liberalism and democracy. Democracy without rights, or an illiberal democracy, degenerates into the tyranny of majority. On the other hand, rights without democracy, that is an undemocratic liberalism, will make of the political system "a playground for billionaires and technocrats" excluding the people from influence on strategic decisions (p. 9). On such grounds Mounk comes out with the following diagnosis:

"In democracies around the world, two seemingly distinct developments are playing out. On the one hand, the preferences of the people are increasingly illiberal: voters are growing impatient with independent institutions and less and less willing to tolerate the rights of ethnic and religious minorities. On the other hand, elites are taking hold of the political system and making it increasingly unresponsive: the powerful are less and less willing to cede to the views of the people. As a result, liberalism and democracy, the two core elements of our political system, are starting to come into conflict" (p. 13).

The rest of the book is devoted to the chase after clues as to the causes and implications of illiberal democracy, or democracy without rights, and undemocratic liberalism, or rights without democracy. In doing so, Yoscha Mounk moves through all areas of the institutional system of modern Western political regimes trying to distribute fairly the blame for the present crisis of democracy between those responsible for the illiberal democratic trend, and those responsible for undemocratic liberalism. Whether he succeeded in his attempt at even-handedness is another matter.

Like Levitsky and Ziblatt, he expresses criticism of direct democracy supporting his view with a quote from Federalist No. 63 by Madison and Hamilton. Madison and Hamilton had in mind the natural human fallibility, and desired to create an institutional system that would increase the chance for error detection and error correction. ${ }^{8}$ They distinguished

8 That was the main point of Vincent Ostrom's The Political Theory of a Compound Republic (1987). 
between democracy, conceived as direct participation in politics, and the republic based on representation, which they promoted. Yet, as Madison noted, "a dependence on the people is, no doubt, the primary control on the government" - although he also added the need for "auxiliary precautions" (Hamilton, Jay, Madison n.d.: 337). Modern states, however, are loaded with a complexity of technical tasks that could not have been imagined even a hundred years ago, and perhaps the "auxiliary precautions" no longer work. Here Mounk's insights are relevant.

He points to the developments eroding the Constitutional separation of powers and expanding the unaccountable administrative state. Examples abound: proliferation of "independent" regulatory agencies whose members the president can fire only for "good cause"; state agencies acting simultaneously as legislator, prosecutor and jury; the power of legislature gradually curtailed by specialized bureaucratic agencies that began to take on a quasi-legislative role; and international treaties and organizations. "This loss of power for the people's representatives is not a result of elite conspiracy. On the contrary, it has occurred gradually, and often imperceptibly, in response to real policy challenges" (p. 60). Moreover, members of legislatures become increasingly estranged from those they are supposed to represent. The ultimate effect of these processes is undemocratic liberalism. Assuming that democracy is "[...] a set of effective institutional mechanisms for translating popular views into public policy [...], in the United States, these mechanisms are now significantly impaired" (p. 92).

Turning to illiberal democratic trends, Mounk perceives the necessity for political actors to adhere to the formal and informal rules of the game. The latter are often vaguely defined which makes it more difficult to notice when they are violated. Democracy deconsolidates: it manifests itself in the thawing of the party system and the propensity of new parties to challenge key norms of the political order. The role of the traditional public media that maintained standards of ethics and served as gatekeepers preventing some abusive messages to reach the public discourse has been subverted by the new social media.

"Until a few decades ago, governments and big media companies enjoyed an oligopoly over the means of mass communication. As a result, they could set the standards of acceptable political discourse. In a well functioning democracy, this might mean declining to publish racist content, conspiracy theories, or outright lies-and thus stabilizing liberal democracy. In an autocracy, this might mean censoring any criticism of the dictator-and thus keeping liberal democracy at bay" (p. 146). 
This is no longer so. Now "[...] the merchants of mendacity also have a much easier time undermining liberal democracies" (p. 147). The populist politician, no longer fettered by old constraints of the old media system, "[...] can spread lies and hatred with abandon." Since societies are no longer culturally homogeneous, "[...] the basic contours of politics and society are being renegotiated. In such times, the disagreements between partisans on both sides grow so deep and nasty that they no longer agree on the rules of the game" (p. 19).

These changes opened the way for populists who have skillfully exploited the popular disorientation. Among the populist politicians, Mounk reserves the top position for Donald Trump, with Victor Orban and Jarosław Kaczyński following suit. Although he criticizes the left for "[...] the radical rejection of the nation and all its trappings," he recognizes nationalism as "the most defining political force of its time." "Nationalism is like a half wild, half domesticated animal. As long as it remains under our control, it can be of tremendous use [...]. But it is always threatening to break free of the constraints we put on it" (p. 215). This affirmation of nationalism looks more like a tactical retreat than an acceptance of the real value of the civic affinity among people sharing common fate.

He also calls for change in the stand adopted by the "defenders of liberal democracy" concerning immigration. By advocating the indiscriminate admission of immigrants, they "simply fan the flames of populism." Thus, "some deviation from their preferred policies may therefore be necessary if they wish to address the deepest drivers of disenchantment with their political system" (p. 214). Hence, they should accept nationalism and the need to improve border controls, as temporarily inevitable evils.

$\mathrm{He}$ is not pessimistic about the future of democracy. He argues that with greater ideological elasticity the "defenders of liberal democracy" will win. Particularly, because "[...] the populists who are now ascendant in so many parts of the world will fail to deliver on their promises and quickly fall from grace" (p. 254).

\section{FROM LIBERAL DEMOCRACY TO "RIGHTS WITHOUT DEMOCRACY" AND “DEMOCRACY WITHOUT RIGHTS"?}

While Yascha Mounk hopes that liberal democracy will ultimately prevail, he also presents strong arguments suggesting the evolution of US political order from liberal democracy to rights without democracy over the decades preceding Donald Trump's election to the White House. He devotes Part 1 consisting of three chapters to the discussion of the crisis 
of democracy. While its discussion would go beyond the modest format of this essay, he identifies a number of structural reasons for transitioning towards rights without democracy. The developments that produced circumstances under which "[...] the views of ordinary people now have "near zero' influence on how their elected representatives act" (p. 78) include the growth of money and lobbying in politics and breakdown in separation of powers. The latter produced by the emergence of independent regulatory agencies and judicial activism (reviews) usurping both legislative and executive powers. The author shows that these trends are not limited to the U.S.

Indeed, empirical evidence provides support to these assertions. In order to assess the extent of the drift away from liberal democracy, we examine the results of international surveys conducted by the Economist Intelligence Unit (EUI), which cover the $2006-18$ period and 167 states and territories. Results are comparable over time as the same methods are used to estimate 60 different indicators assessing developments in electoral process and pluralism, civil liberties, the functioning of government; political participation, and political culture. The result is a synthetic single estimate of the Democracy Index (DI) taking values between 0 and ten. States with values of DI above 8 are classified as "full democracies;" (these can be treated as meeting Mounk's criteria of liberal democracy) those with values below 8 and above 6 are "flawed democracies;" states with values below 6 and above 4 are "hybrid regimes"; and below 4 are authoritarian regimes. ${ }^{9}$

The major conclusion that can be drawn from comparisons of the rankings between 2006 and 2018 is that-except for a significant deterioration amongst democratic states - the number of states with non-democratic regimes has remained remarkably stable. The number of states with "authoritarian regimes" barely changed during this period: their number fell from 54 (of the total of 167 states and territories covered by surveys) in 2006 to 52 in 2018. Second, the number of countries with "hybrid regimes" increased from 29 to 38 thanks to two 'newcomers' from authoritarian class and seven dropouts from the "flawed democracies" category, whose total number-as a result of incomers from the "full democracies" —remained the same: 54 in both 2006 and 2018. "Hybrids" are benevolent autocracies at worse. Last but not least, the group of "full democracies" shrank by around a quarter from 27 to 20 states. In all, however, the share of the number of states with either full or flawed democratic governance

\footnotetext{
${ }^{9}$ See: www.eiu.com/topic/democracy-index
} 
in the total fell by six percent between 2008 and 2018; while that of full democracies by 33 percent (see Figure 1).

Hence, although the data do not seem to point to a significant contraction of democratic states worldwide, as Larry Diamond (2015) suggested, they clearly corroborate Diamond's other point about a gradual decline in civil liberties and democratic values that has already lasted for at least the last decade. The contraction of the reach of "full democracies" illustrates this point. The dramatic decline in the number of states meeting the criteria of a "full democracy" in 2008-18 raises several questions, which will be addressed throughout this essay.

Figure 1

Backsliding of "Full Democracies" (in \% of the total number of surveyed countries) and values of Democracy Indices of the US in 2006-2018

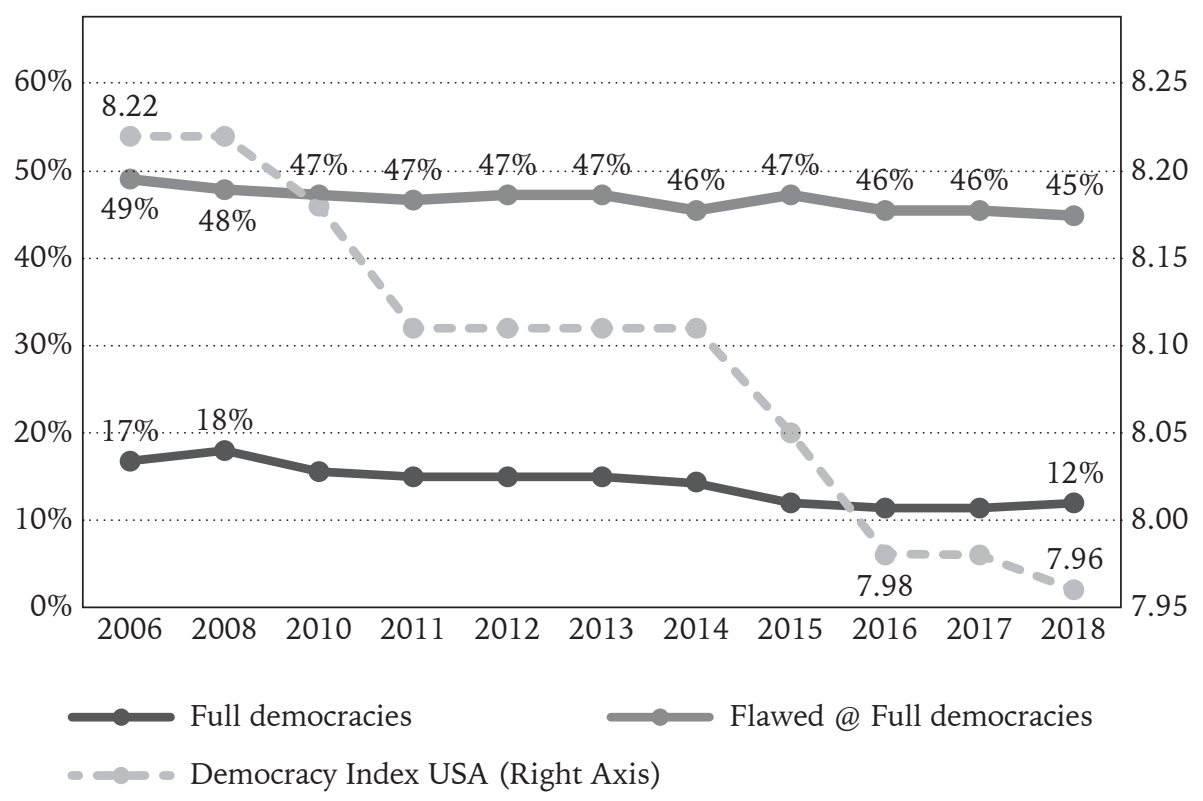

Source: www.eiu.com/topic/democracy-index), derived from the data for selected years.

Most strikingly, the US is no longer classified as "full democracy": she lost this status in 2016. As the authors of the report "Democracy Index 2016: Revenge of the "deplorables" note, "the US has been teetering on the brink of becoming a 'flawed democracy' for several years, and even if there had been no presidential election in 2016, its score would have slipped be- 
low 8.00." 10 This was clearly not the result of Donald Trump's victory in November 2016 as he was sworn into office next year. The United States' highest score of 8.22 was earned back in 2006 and again in 2008. Subsequently, it fell to 8.11 in $2011-14,8.05$ in $2015,7.98$ in 2016-17, and slightly deteriorated in 2018 falling to 7.96 (see Figure 1).

While the Brexit vote strikes one as driven by different considerations, there are some similarities. Voters' uneasiness with outsourcing national sovereignty was one of them-in the UK to Brussels, and in the US to multilateral institutions. Concerns about the loss of national identity as a result of the influx of immigrants exceeding respective adaptive social and cultural capacities seems to have played a role as well. These concerns can be interpreted as motivated by the desire to protect democracy rather than to destroy it, especially since the UK exited the arrangement described by Mounk as "Undemocratic Liberalism" (p. 59).

Thus, populist-authoritarian tendencies can be seen as a reaction to political systems becoming "[...] less effective at translating popular views into public policies" with the result of "[...] many important topics [having] been taken out of political contestation over the past decades" (p. 77). As we shall argue, however, there were deeper reasons for the rejection of elitism.

\section{NATION-STATE AND NATIONAL IDENTITY: CRITICAL INGREDIENTS ALMOST COMPLETELY IGNORED?}

The books that inspired this essay have at least three features in common: (i) they abstract from the international environment in which the democracies function; (ii) they do not follow Milton Friedman's aphorism; "there is no such a thing as a free lunch" and completely neglect that by assigning priority to one value while we sacrifice other values; and (iii) they ignore rich literature and important analytical studies of vulnerabilities of liberal democratic regimes accumulated over the last two centuries. Particularly, over the last half century important research has been undertaken focusing on the secular longitudinal trends in culture that undermine the liberal democratic regimes. We shall devote the last part of the essay to the discussion of these topics.

The works discussed in this paper, particularly the one by Norris and Inglehart, convey the impression that we live in a secure world. Personal

\footnotetext{
10 See the webpage: http://felipesahagun.es/wp-content/uploads/2017/01/DemocracyIndex-2016.pdf
} 
insecurity is part of the definition of authoritarianism: whoever feels insecure belongs to the authoritarian type. Yet, in the present world, personal security is directly connected to security in international political, military, and economic relations. To the same category belong those who feel uneasy with the present state of political systems-are critical of the elites, and display lack of trust in political institutions. We surely find people, at the extreme poles of the Norris' and Inglehart's continua, whose attitudes may contribute to instability of liberal democratic regimes. However, a certain feeling of dissatisfaction with the way countries are governed and of insecurity in the modern world seems justified.

The present world economic order was designed at the Bretton Woods Conference and implemented in its aftermath. The IMF, World Bank, and GATT/WTO have up to now provided underpinnings for the smooth functioning of markets and economic growth. The judgment about the United Nations Organization and its Security Council as instruments of enforcement of international law is not so favorable. During the first forty years of its existence, the UN had been stalemated by the vetoes of USSR and its allies. Now, the same function is performed by Russia and China. At the global level, the rule of law is largely a fiction.

Years ago, Zbigniew Brzezinski (1997) warned that the worst future scenario for United States would be the Sino-Russian alliance. This alliance is now a fact, and it is directed against United States. China fights American influence in the Asia Pacific region; Russia strives to push America out of Europe, while another of her objectives is to subvert European integration. Considering that the present world economic and political order rests on the United States, the success of such a strategy could have catastrophic consequences for the whole world. Western Europe, demoralized by a long period of prosperity under the American umbrella, deprived of effective leadership, has up to now been unable to address even the most pressing challenges facing the EU, and the continent.

China and Russia are only part of the problem. Another challenge is presented by the failed states: societies unable to build and sustain a stable political and economic order. The failed states are exploited by China, and to a lesser extent by Russia, as a source of cheap raw materials but also as an instrument to destabilize the West. Here we encounter the problem of immigration.

Dominant cultures project their value systems and institutional patterns to the outside world. This has also been the case with the West: the ideas of democratic legitimacy represented by elections, the doctrine of separations of powers and a system of checks and balances have been 
widely accepted. Even the totalitarian regimes adopted appearances of Western constitutionalism.

Yet, many societies have been unable to build viable political and economic regimes. Those that possess natural resources, are usually ruled by ruthless dictators, or come close to chaos. In both cases, the result are millions of people dreaming about finding refuge in the highly developed world. An unconstrained reception of such waves of immigrants would mean, that instead of the Western extrapolation of stability and organization to the outside world; the West would turn into a recipient of chaos and disorganization. Citizens of the West have good reasons to feel insecure when faced with the danger of uncontrolled mass migrations from Africa, Middle East or Latin America. The downfall of the West will not help nations in distress. People who feel fully secure under such circumstances must be very naïve.

The most serious theoretical disagreement between us and the authors of these works concerns the treatment of the nation-state: the notion is disregarded by Levitsky and Ziblatt, Norris and Inglehart seem to judge the institution as obsolete, while Mounk (p. 23) observes that in order to "[...] preserve democracy without giving up on the emancipatory potential of globalization, we need to figure out how the nation state can once again take control of its own fate." This is a serious omission. Consider first that nation states are a highly heterogenous group in terms of civilization, culture, external strategies and political systems. Readers of the discussed books might get the impression that we live in a world consisting exclusively of democracies sharing basic values. But there are friends and foes alike; and relations with them may profoundly affect domestic developments. As we shall see borders do matter.

Furthermore, nation states are major actors and building blocks of globalization as they are responsible for managing flows of goods, services and people across borders and are responsible for fulfilling commitments stemming from participation in multilateral government organizations, which underpin global interaction. Nations states are as strong as their boundaries. Boundaries are the rules that regulate what or who is let into or out of the system. The authors praise "inclusive institutions" and equate them with liberal democracy. This is a misunderstanding: no system can exist without boundaries. Every institution is inclusive and exclusive at the same time. They may differ only in terms of the rules governing the inclusiveness/exclusiveness and their extent.

This brings us back to the institution of citizenship that implies the moral duty to engage in support of the political system and, if necessary, 
to sacrifice one's particular interests for the sake of the whole. One cannot expect such an attitude in the absence of a feeling of solidarity with fellow citizens. This is what is meant by patriotism. Patriotism does not imply a conviction of the superiority of one's nation over the others: a sense of responsibility for one's country does not imply disregard for the fate of other human beings.

Patriotism does not exclude cosmopolitanism. As Leszek Kołakowski (2009: 158-159) put it, "there is no incurable opposition between the cosmopolitan posture in all areas of life, in which it is well-grounded, and an attachment to one's own national heritage". He was aware of the nationalist threat and saw in cosmopolitism a necessary bid for ethnic blindness. The opposition between nationalism and cosmopolitism is justified, but not in the case of patriotism, which is a necessary component of the civic ethos. The identification of patriotism with nationalism is misleading. "The basic ambiguities inherent in all languages are radically increased when incentives exist to obfuscate meaning" (Ostrom 1997: 9).

Respect for what is valuable in our past is a necessary element of the institution of citizen. The future can only be founded on elements of the past. As Edmund Burke (1969: 119) famously remarked, "People will not look forward to posterity, who never look backward to their ancestors." What does this have to do with authoritarian populism?

The "cultural silent revolution" was already the topic of Daniel Bell's Cultural Contradictions of Capitalism, a book that appeared over forty years ago. Bell's conclusions contradict however those put forward by Norris and Inglehart as serving the democratic cause. He noted, for instance, that:

"The emphasis of modernism is on the present or on the future, but never on the past. Yet, when one is cut off from the past, one cannot escape the final sense of nothingness that the future then holds. Faith is no longer possible, and art or nature or impulse can erase the self only momentarily in the intoxication of frenzy of the Dionysian act. But intoxication always passes, and there is the cold morning after, which arrives inexorably with the break of the day" (Bell 1978: 50).

Bell appreciates the importance of religion as a factor imposing moral norms on culture. "It insists on limits, particularly the subordination of aesthetic impulses to moral conduct". Modernism "[...] as a cultural movement trespassed religion and moved the center of authority from the sacred to the profane" (Bell 1978: 158). The secularization of social life is not without costs.

In Bell's view, the post-modernist doctrine subverts the middle-class values. Commenting on post-modernist work of Michel Foucault, he 
wrote, that "it is no longer the decline of the West, but the end of all civilization" (Bell 1978: 52). The present predicament of Western liberal democracies is well taken in Bell's diagnosis:

"The foundation of any liberal society is the willingness of all groups to compromise private ends for the public interest. The loss of civitas means either that interests become so polarized, and passions so inflamed, that terrorism and group fighting ensue, and political anomia prevails; or that every public exchange becomes a cynical deal in which the most powerful segments benefit at the expense of the weak" (Bell 1978: 245).

This diagnosis could probably be shared by the authors of the works under discussion, but the factors that, according to Bell, produced it, differ. Moreover, Bell's anxiety concerning the future of liberal democracies had nothing to do with personalities of political leaders-he analyzed longitudinal trends in the development of Western culture and social structures and their impact on political and economic institutions.

The present nation-state faces dilemmas that could not have been foreseen at the time. It is squeezed between the challenges of an increasingly more complex global political and economic system, and the burden of internal expectations and pressures. Both endogenous and exogeneous pressures had a centralizing and bureaucratizing effect on the state; "every institutional arrangement has limits and is the source of potential failure" (Ostrom 1997: 15). Up to the present, liberal democracies have shown an impressive ability to adapt to new circumstances and to learn from crises. The question is whether they still have this ability to learn.

\section{PERILS OF RADICAL EGALITARIANISM?}

Another work devoted to the crisis of Western liberal democracies, with a diagnosis radically different from those presented in the books under review, is Aaron Wildavsky's The Rise of Radical Egalitarianism (1991). Wildavsky distinguished four types of political cultures: hierarchical collectivism, competitive individualism, radical egalitarianism, and fatalism. In his discussion of Western political systems, he took into account only the first three. Each culture gives a different answer to basic questions concerning the preferred social order. Until the 1960s, hierarchical collectivism and competitive individualism had dominated the political-economic organization in the West, while at the same time each opposed the other. The former is characterized by the centrally imposed division of labor, inequality of position regulated by formal norms, emphasis on legal equality, and envy controlled by the meritocratic ideology. The latter is 
based on the freedom of contract, leaders are selected by bidding and bargaining, envy is mitigated by showing that everyone has a chance. "Taken together, the alliance of these two cultures-hierarchy and individualism - constitutes the modern social establishment. From hierarchy comes order (including the rules for competition), and from individualism comes economic growth" (1991: 103).

Radical Egalitarianism is opposed to both these cultures. "Where competitive individualism believes in equality of opportunity, egalitarian collectivism believes in equality of results. Those who wish to reduce authority so as to promote individual differences and those who reject authority so as to reduce individual differences are far apart. While individualism encourages all transactions that maintain competition, egalitarianism rejects all bargains that increase disparities among people". Radical egalitarianism is animated by the "organization without authority" (Wildavsky 1991: 103).

Hierarchical collectivism and competitive individualism are complementary: "the strong group boundaries and strong prescription of behavioral norms in hierarchies reinforce one another; as do weak boundaries and lack of prescriptions in individualistic markets." The egalitarian demands are inconsistent, because the rejection of authority and redistribution of resources cannot be reconciled" (Wildavsky 1991: 112). By making contradictory demands, they demoralize the government. They break conventions and have claims, but do not want to accept responsibility for the results of their actions.

Radical egalitarians form sectarian groups promoting single issues like environment, immigrants, LGBTQ rights, etc. In fighting for the issues that concern them, they appeal directly to the general public resorting to opportunities offered by modern communications technology. They omit thereby the mediating structures-political parties, trade unions, churches, that is, the hierarchies which until recently had processed such demands, before they reached the political center. As a result, the central institutions of the government are overburdened with contradictory claims and expectations that they cannot meet. As usual, decision makers must choose among competing goals. But these appeals are practically inconsequential as long as the hierarchies that could aggregate and strike compromises amongst various contradictory claims and values falter.

The single-issue groups are sectarian, because they do not accept the legitimacy of other claims. They also reject impersonality in public life. As Richard Sennett noted in The Fall of Public Man, traditionally, the public was the realm of cosmopolitan, impersonal, civilized behavior, while the 
family belonged to the realm of nature. "The very fear of impersonality which governs modern society prompts people to envision community on an even more restricted scale" (Sennett 1978: 263). Thus, to gain inclusion, one must exclude: for an environmentalist the coal miner who does not want to lose his job is an enemy of humanity; for a homosexual person someone who is hesitant on the issue of adoption of children by homosexual couples is a homophobe, etc. This excludes a rational discourse. The problem of modern liberal democracies starts with neglect of the institution of citizenship.

Not only hierarchies are under threat, this is also the fate of competitive individualism. In a recently published book, Thomas Philippon (2019) argues that key problems facing the American economy stem mainly from the growth in concentration of corporate power. Large corporations' lobbying against competition assures raising profits, but at the level of national economy it depresses investment, innovation, and growth. Indeed, empirical analysis of 181 members of The Business Roundtable, who recently rejected priority of maximizing shareholders' value by putting it on a par with other "stakeholders," i.e., communities, employees, customers and suppliers produced sobering results pointing to their collusion with the state (Raghunandan, Rajgopal 2019). Their distinctive features setting them aside from non-members of The Business Roundtable include among other: these are very large corporations with market shares 5 percentage points higher than those of peer firms; they reported in 2014-18 a much higher incidence of compliance-related violations of regulations set by the Environmental Protection Agency and the Occupational Safety and Health Administration; and CEOs of these companies earn more than those in peer firms but achieve lower stock returns at the expense of shareholders. In all, they collude with the state to expand its reach and create fertile ground for rent seeking; they have a strong incentive to promote actions raising entry costs and pre-empt regulatory scrutiny that might expose rent-seeking behavior. As Mancur Olson (1982) elegantly showed in his vision of how economies rise and fall, powerful special-interest lobbies obstruct change, which threatens their interests, making it almost impossible to innovate.

Growing concentration of industries not only raises the cost of entry and, by the same token, limits competition but also creates fertile conditions for capture of public policy by vested private interests and expansion of administrative state. Given the complexities involved, implemented policies produce not only winners but also losers. Financial interdependence increased the probability of transmissions of problems, once these 
emerge, to other regions of the world while fragmentation of production processes resulted in transfer of production facilities to countries with cheaper labor costs. Thus, pressures to manage increasing complexities of globalization and domestic economy have called for expansion of regulations and bigger state; taken together, they tend to limit both individual freedoms, and accountability of the ruling elite to the people. Here is the real problem before Western democracies.

\section{CONCLUDING COMMENT}

Turning to the question whether democracy is doomed to extinction, these three books taken together unexpectedly offer some reasons for at least an ounce of optimism, i.e., its possible reversibility. Except for Hugo Chevez in Venezuela, other "authoritarian populists" did not nationalize major sectors of the economy. The existence of a huge state-owned sector erects a huge barrier to transitioning back to democracy. In the U.S. the movement has been in the opposite direction: dramatic deregulation in 2017-19 increased economic freedoms and slashed the scope of state's micromanagement of the economy. Hence, in the presence of a dominant private sector, possible internal pro-democracy pressures in the future will have a better chance of surfacing and succeeding in reversing populist backslides.

Furthermore, all the authors seem to be moderately optimistic that democracies will withstand populist assault and return to a previous liberal trajectory. They argue that populist leaders will not be able to deliver promised goodies and may be thrown from power. In addition, major help is supposed to come from demographics: older conservative cohorts will die while ageing Millennials_-who favor post-materialist values ${ }^{11}$-will have a decisive voice in the ballot. For them, since they see the threat to the survival of democracy coming almost exclusively from authoritarian populism, this would not be the end of democracy. To the contrary, it would survive. But is this optimism well founded?

The answer is unambiguously negative: if one agrees with Daniel Bell's and Aaron Wildavsky's analysis of factors underpinning democracy, it will doom democracy. Post-materialist values and metropolitan elitism, shared

\footnotetext{
11 Actually, they value socialism over capitalism. The Reason-Rupe survey found that 53 percent of 18- to 29-year-olds view socialism favorably, compared to only a quarter of Americans over 55 (see: https://thefederalist.com/2016/02/15/why-so-many-millennialsare-socialists/).
} 
by Millennials and by the authors of the reviewed books, are conceived as functional from the point of view of liberal democratic survival. But these values run counter to what Daniel Bell and Aaron Wildavsky identified as major threats to Western civilization. These threats are best captured by Wildavsky's notion of radical egalitarianism promoting equality of results at the expense of equality of opportunity. Egalitarian collectivism believes in equality of results. Promoting equality of results at the expense of equality of opportunity is a threat to individual freedoms and implies reverse discrimination based on race, gender, sexual orientation, etc. Its side effect, facilitated by the digital age, is "cancel culture," i.e., suppression of expression of ideas and legitimate debate.

Counter-populism developments in the dominant values system, suggested in particular by Norris and Inglehart, internalization of post-modernist identity politics, and protection of minority rights at the expense of a shared common value system, all figure predominantly in Bell's diagnosis of threats to civilization and democracy. In brief, post-materialist values, including identity politics and political correctness, underpinning metropolitan elitism are not only incompatible with liberal democracy but also may spell its extinction. Their views can be dismissed as coming from a "prewar cohort," but can we disregard intentionally Plato, Aristotle and hundreds of other important thinkers of the past?

Viewed in Bell's and Wildavsky's perspective, counter-populism might be regarded as the "cultural backlash," that is, a healthy reaction of concerned citizens seeking to address cultural disintegration and the collapse of other indispensable underpinnings of liberal democracy. The propensity to succumb to populism, including authoritarian populism, is not necessarily due to obscurantism, let alone to "politically incorrect views" - to quote Norris and Inglehart. The authoritarian variant of populism could then be interpreted as a healthy, albeit perhaps not wholly rational, response to real threats to our Western civilization.

Traditionally the liberal-democratic doctrine assumed that an equilibrium between the rulers who have always sought to dominate and the society that has fought to keep such ambitions in check critically hinges upon the institution of citizenship, and its manifestation in the form of civil society. The authors of the reviewed books not only neglect these dimensions of democracy. They write about human rights and other measures to address historical grievances of various minorities paying only lip service to institutional implications of their implementation. Formalized 
rights become laws, which in turn requires their enforcement and thereby further expansion of the centralized state bureaucracy into areas of social life that once had been the preserve of the civil society. This produces problems with governance and exacerbates disequilibrium between the state and society. If this happens, liberal democracy is in deep trouble. One may wonder whether ideas promoted in the reviewed books, with a hesitant exception of Yascha Mounk's, provide a cure to the present political malaise or, perhaps, are an integral part of it?

\section{REFERENCES}

Bell, Daniel. 1978. The Cultural Contradictions of Capitalism. New York: Basic Books.

Brzezinski, Zbigniew. 1997. The Grand Chessboard: American Primacy and Its Geostrategic Imperatives. New York: Basic Books.

Burke, Edmund. 1969. Reflections on the Revolution in France. New York: Penguin Books.

Canovan Margaret. 1999. "Trust the people! Populism and the two faces of democracy." Political Studies 47: 2-16.

Constant Benjamin. 1997. Principes de Politique. Paris: Hachette Littératures.

Diamond, Larry. 2015. "Facing up to the democratic recession." Journal of Democracy 26, no. 1. Hamilton, Alexander, John Jay, James Madison. [1787] (n.d.). The Federalist. E. M. Earle (ed.). New York: Random House Modern Library.

Inglehart, Ronald. 1977. The Silent Revolution: Changing Values and Political Styles Among Wester Publics. Princeton: Princeton University Press.

Inglehart, Ronald. 1990. Culture Shift in Advanced Industrial Society. Princeton: Princeton University Press.

Kołakowski, Leszek. 2009, Czy Pan Bóg jest szczęśliwy i inne pytania [Is God happy and other questions]. Kraków: Znak.

Olson, Mancur. 1982. The Rise and Decline of Nations: Economic Growth, Stagnation and Social Rigidities. New Haven, CT: Yale University Press.

Ostrom, Vincent. 1987. The Political Theory of a Compound Republic: Designing the American Experiment, $2^{\text {nd }}$ edition. Lincoln-London: University of Nebraska Press.

Ostrom, Vincent. 1997. The Meaning of Democracy and the Vulnerability of Democracies. Ann Arbor: The University of Michigan Press.

Philippon, Thomas. 2019. The Great Reversal: How America Gave Up on Free Markets. Cambridge Mass: Harvard University Press.

Raghunandan, Aneesh, Shiva Rajgopal. 2019. "Is there real virtue behind the Business Roundtable's signaling?” The Wall Street Journal, December 2.

Sennett, Richard. 1978. The Fall of the Public Man: On the Social Psychology of Capitalism. New York: Vintage Books.

Wildavsky, Aaron. 1990. „Robert Bork and the crime of inequality”, National Affairs, no. 42 (https://www.nationalaffairs.com/public_interest/detail/robert-bork-and-the-crime-ofinequality).

Wildavsky, Aaron. 1991. The Rise of Radical Egalitarianism, Washington, D.C.: The American University Press. 


\begin{abstract}
Recent years have witnessed the publication of a number of research papers and books seeking to assess threats of electoral victories of anti-establishment politicians and political parties, described as authoritarian populists. This essay focuses on three books directly addressing the origins and threats of authoritarian populism to democracy. It consists of six sections and the conclusion. The first section presents findings (Norris and Inglehart) based on surveys of values of voters of various age cohorts concluding that authoritarian populism is a temporary backlash provoked by the post-materialist perspective. The second section examines the contention, spelled out in Levitsky and Ziblatt, that increase in openness of American political system produced, unintentionally, a degradation of the American political system. The third section continues brief presentations focusing on to the causes and implications of "illiberal democracy," and "undemocratic liberalism" (Mounk). The fourth section examines developments in the quality of democracy in the world showing that despite the decline in Democracy Indices, overall there was no slide towards non-democratic forms of government in 2006-2019. The next two sections deal with dimensions missing in reviewed books; the notion of nation-state, international environment, civic culture and, in particular, dangers of radical egalitarianism to democracy. The last section concludes with regrets that the authors ignored rich literature on fragility of democracy and failed to incorporate in their analyses deeper structural factors eroding democracy: by the same token, return to the pre-populist shock trajectory is unlikely to assure survival of liberal democracy.
\end{abstract}

Keywords: liberal democracy, illiberal democracy, populism, authoritarian populism, libertarian populism, cultural silent revolution, citizenship, democratic backsliding, primaries, nation state, nationalism, patriotism, the rule of law, immigration, open borders, globalization, modernism, post-materialism, radical egalitarianism, competitive individualism, metropolitan elitism, EUI Democracy Index 